\title{
Formation of a Portfolio of High-Tech Industries to Ensure Sustainable Development of the Region
}

\author{
Z. Vasilyeva*, I. Filimonenko, T. Likhacheva, A. Moskvina, V. Borodkina \\ Siberian Federal University, Krasnoyarsk, Russia \\ ${ }^{*}$ Corresponding author. Email: iubpe@sfu-kras.ru
}

\begin{abstract}
The relevance of the study is due to the need to identify and develop promising markets for high-tech products for traditional and new rapidly developing sectors of the economy of Russian regions. The solution to the problem is associated with ensuring national security through the formation of the availability of necessary goods and services for the population, business and the state, as well as with the need to embed production in world commodity markets for the strategic repositioning of the region and creating conditions for sustainable socio-economic development. The purpose of the article is to develop a methodological approach to the formation of a portfolio of high-tech industries of existing and new types of products that, due to their competitiveness, are able to satisfy domestic investment demand, including the needs of import substitution, external demand and ensure sustainable development of the region. The article examines the multi-criteria process of forming a portfolio of high-tech products in the economy of the region. The methodological stages of the product portfolio formation include localization of the selection of promising businesses from the standpoint of technology and efficiency among the high-tech economic activities existing in the region; identification of the list of high-tech enterprises and assessment of the potential for the development of hightech industries from among the priority areas of the development of science and technology of the Russian Federation; formation of a portfolio of high-tech industries based on an assessment of the scale of market potential and the level of competitiveness of products (priority or promising for production in the region) on the national and global commodity markets. The formation of a portfolio of high-tech products is based on the methodology of positioning according to the priorities of promotion in the national and global commodity markets, and is considered as a decision-making tool in the territorial and sectoral context in order to ensure sustainable development of the region's economy. Approbation of the methodological approach is presented on the example of high-tech industries of the Krasnoyarsk Territory.
\end{abstract}

Keywords: portfolio of high-tech products, sustainable development of the region, promising commodity markets, market positioning.

\section{INTRODUCTION}

The role of high-tech markets in the socio-economic development of regions is rapidly increasing, providing the economy with new growth trajectories, transforming the structure of the economy and defining a new system of challenges for science, technology and innovation policy.

For example, the global nanotechnology market has demonstrated steady growth rates in recent years - at least $15-20 \%$ per year. The volume of the global market of information and communication technologies is growing by $3-5 \%$ annually, providing $6-7 \%$ of global GDP.
In the global markets for high-tech products, the position of the Russian Federation is not so significant in comparison with other countries. Exporting enterprises operate within the narrow specific areas of high-tech products, such as energy equipment, automatic machinery, instrumentation. Russia's share in the global technology sector is about $0.3 \%$, in the nanotechnology market - $0.04 \%$; information and communication technologies $-0.08 \%$.

Achieving the international competitiveness of Russian goods is one of the priority tasks of the state. However, the content analysis of scientific publications on the research topic showed the ambiguity of methodological approaches to assessing the priority and prospects of high-tech industries and substantiating their 
role in the sustainable development of regions $[1,2,3,11]$. At the same time, requests for activation of the innovative and technological development of the regions actualize the task of finding priorities among the manufactured high-tech products that are in demand on the national and global markets. As noted in the document "Prospects for increasing Russian nonresource exports" [10], there are two main ways for Russia to develop new markets - the placement of production facilities of foreign companies on the territory of the state and brining competitive products of domestic enterprises to global markets. However, the task is extremely difficult because, firstly, it requires large-scale investments in marketing (development of our own brands, ensuring competitiveness, generating demand, promotion). Secondly, the search for a solution to this problem will have to be carried out in the context of strengthening protectionist measures and the introduction of new export support services in foreign countries.

In 2018, the Krasnoyarsk Territory ranked 71st among 82 constituent entities of the Russian Federation in terms of the share of high-tech and knowledgeintensive industries in the GRP. Over the past 5 years, this indicator has decreased from $16.7 \%$ to $13.6 \%$. Enterprises of the processing sector of the Krasnoyarsk Territory (according to the FSGS) are classified as medium-tech high-level, for which the ratio of $\mathrm{R} \& \mathrm{D}$ costs to value added ranges from $2.5 \%$ to $8 \%$. In 2017 2018 , the indicators worsened due to a sharp reduction in R\&D costs, shifting manufacturing industries to the group of medium-tech low-level ones.

The commodity structure of the region's exports of the current period is dominated by metals and products made from them (64\% in 2018). At the same time, the mechanical engineering sector associated with the production of power equipment for mining, metallurgy, oil and gas industry, etc. has great prospects. The markets of Asia, Africa, Latin America, and the CIS are promising for the supply of finished machinery and equipment.

The importance of identifying and developing promising commodity markets for the Krasnoyarsk Territory is associated, on the one hand, with ensuring national security through the formation of accessibility of necessary goods and services for the population, business and the state, on the other hand, with the need to integrate production facilities into global commodity markets for strategic repositioning of the region and creating conditions for sustainable socio-economic development.

This makes it necessary to assess the development potential of high-tech products markets for traditional and new rapidly developing sectors of the economy. The purpose of the article is to develop a methodological approach to the formation of a portfolio of high-tech industries of existing and new types of products that, due to their competitiveness, are able to satisfy domestic investment demand, including the needs of import substitution, external demand and ensure sustainable development of the region.

\section{MATERIALS AND METHODS}

To achieve this goal, the authors propose the following stages in the formation of a portfolio of hightech businesses in the regional economy:

localization of the choice of promising businesses from the standpoint of manufacturability and efficiency among the types of economic activities existing in the region, related to the number of high-tech ones;

clarification of the list of high-tech enterprises in the region and assessment of the potential for the development of high-tech industries from among the priority areas for the development of science and technology in the Russian Federation;

formation of a portfolio of high-tech industries based on an assessment of the scale of market potential and the level of competitiveness of products (priority or promising for production in the region) on the national and global commodity markets.

At the first stage of the study, in order to develop the system of commodity markets in the region and increase its competitiveness, the types of economic activities of high and medium high technological level that are promising for the socio-economic development of the region are identified and coordinated. The basis for the identification is the Methodology for calculating the indicators "The share of products of high-tech and knowledge-intensive industries in the gross domestic product" and "The share of products of high-tech and knowledge-intensive industries in the gross regional product of the subject of the Russian Federation" (Appendix 1) [6]. The list for the economy of the Krasnoyarsk Territory includes the following types of economic activities (table 1).

At the second stage, the list of high-tech enterprises in the region is being clarified and the potential of hightech industries from among the priority areas of development of science and technology of the Russian Federation is being evaluated. Enterprises related to the types of economic activities of a high-tech level are, as a rule, closed in the information field. Therefore, for the purpose of research, it is advisable to conduct an expert survey based on electronic services (Google Forms, Yandex. Vzglyad, Survey Monkey, QuestionStar, Anketolog). 
Table 1. Priority types of economic activities of high and medium high technological level, implemented in the region.

\begin{tabular}{|c|l|}
\hline OKVED & \multicolumn{1}{c|}{ Name } \\
\hline \hline \multicolumn{2}{|c|}{ High-tech industries } \\
\hline 26 & $\begin{array}{l}\text { Manufacture of computers, electronic and optical } \\
\text { products }\end{array}$ \\
\hline 30.3 & $\begin{array}{l}\text { Manufacture of aircraft, including spacecraft, } \\
\text { and related equipment }\end{array}$ \\
\hline \multicolumn{2}{|c|}{ Medium high tech industries } \\
\hline 27 & Manufacture of electrical equipment \\
\hline 28 & $\begin{array}{l}\text { Manufacture of machinery and equipment not } \\
\text { included in other categories }\end{array}$ \\
\hline 29 & $\begin{array}{l}\text { Manufacture of motor vehicles, trailers and } \\
\text { semi-trailers }\end{array}$ \\
\hline 30 without & $\begin{array}{l}\text { Manufacture of other vehicles and equipment } \\
\text { (excluding the construction of ships, ships and } \\
\text { boats; manufacture of aircraft, including space, } \\
\text { and related equipment) }\end{array}$ \\
\hline 32.5 & $\begin{array}{l}\text { Manufacture of medical instruments and } \\
\text { equipment }\end{array}$ \\
\hline 33 & $\begin{array}{l}\text { Repair and installation of machinery and } \\
\text { equipment }\end{array}$ \\
\hline
\end{tabular}

The main objectives of the survey are:

- determination of the main types of high-tech products and main consumer industries;

- study of the export potential and problems in the promotion of high-tech products to international markets;

- study of plans for the release of new high-tech products and its potential consumers;

- study of plans for the development of innovative high-tech products;

- studying the experience of state support.

- The survey results allow us to present:

- types of high-tech industries in the context of OKVED;

- a list of products by OKVED and existing or promising markets;

- importing countries of products;

- a list of new types of high-tech products planned to be launched on world markets.

At the third stage of the study, the competitiveness of high-tech industries in the region, the main products of high-tech manufacturing in the domestic market of the Russian Federation and global commodity markets is assessed. This stage ends with the positioning of the region's high-tech products in the space of the matrix "the priority of promotion on the global commodity markets - the priority of promotion on the national market of the Russian Federation". The goal of the stage is to differentiate the products of high-tech industries according to three development priorities (higher, medium, lower) to meet domestic and external investment demand.

Thus, the third stage of the study includes four successive stages.

\subsection{Assessment of the Competitiveness of High-Tech Industries in the Region Based on the Level of Manufacturability}

. The goal is to identify enterprises in the region with a high technological level based on the threshold values of the manufacturability indicator [7].

The calculation of the indicator of manufacturability of the enterprise (Tech.pr) is carried out in accordance with the formula (1):

$$
\text { Tech.pr }=\text { FEpr }+ \text { MEpr, }
$$

where FEpr - capital intensity of the enterprise; MEpr - material consumption of the enterprise.

High-tech enterprises include those for which the manufacturability indicator meets two conditions simultaneously:

- value of more than 0.2 rubles per 1 rub of cost (threshold levels are selected based on statistical analysis of the values of similar indicators for the branches of the Russian economy, grouped in accordance with the methodology of Rosstat);

- the value of the manufacturability indicator exceeds the value of the salary capacity (indirect assessment of investments in technological innovations).

Initial data for the calculation - DB FSGS, IS SPARK Interfax, results of a survey of business representatives.

\subsection{Assessment of the Competitiveness of the Main Products of High-Tech Industries in the Domestic Market of the Russian Federation}

The goal is to differentiate high-tech products of the region based on the potentials of domestic supply and demand, as well as the potential of import substitution in three priorities (highest, middle, lowest), each of which is assigned based on the calculation of the integral indicator of competitiveness in the domestic market (Int ${ }^{\mathrm{RF}}$ ) in accordance with the formula (2):

Int $\mathrm{RF}=$ Int demand $* 0.4+$ Int $^{\text {offer }} * 0.2+$ Int $^{\mathrm{IZ}} * 0.4$, 
where Int demand is an integral indicator of competitiveness for consumer industries; Int offer - an integral indicator of competitiveness against competitors; Int IZ - an integral indicator of competitiveness in terms of import substitution potential; $0.4,0.2$ and 0.4 are the weight coefficients of the significance of the indicators.

Each value of the integral indicator of the competitiveness of a product group in the domestic market (Int ${ }^{\mathrm{RF}}$ ) corresponds to a position among the values of indicators for all product groups with a distribution into four groups: maximum value, value above average, value below average, minimum value. Determination of boundaries for four product groups is based on the approach proposed by G.L. Azoev for groupings of indicator values (Iint ${ }^{\mathrm{RF}}$ ) in conditions of lognormal distribution [4,5] (table 2).

Table 2. Formulas for calculating the boundaries of commodity groups ${ }^{*}$.

\begin{tabular}{|c|c|}
\hline Indicator level & $\begin{array}{l}\text { Formulas for calculating the boundaries of } \\
\text { four product groups }\end{array}$ \\
\hline Maximum & {$\left[\left(\text { Iint }^{\mathrm{RF}}\right)_{\text {avg }}+3 \sigma_{1},\left(\text { Iint }^{\mathrm{RF}}\right)_{\max }\right]$} \\
\hline Above average & {$\left[\left(\operatorname{Iint}^{\mathrm{RF}}\right)_{\text {avg }},\left(\operatorname{Iint}^{\mathrm{RF}}\right)_{\text {avg }}+3 \sigma_{1}\right]$} \\
\hline Below average & {$\left[\left(\right.\right.$ Iint $\left.^{\mathrm{RF}}\right)$ avg $-3 \sigma_{2},\left(\right.$ Iint $\left.^{\mathrm{RF}}\right)$ avg $]$} \\
\hline Minimum & {$\left[\left(\operatorname{Iint}^{\mathrm{RF}}\right) \min ,\left(\operatorname{Iint}^{\mathrm{RF}}\right)\right.$ avg $\left.-3 \sigma_{2}\right]$} \\
\hline
\end{tabular}

Accepted designations: ( Iint $\left.{ }^{R F}\right)_{\text {min }}$, ( $\left.\operatorname{Iint}^{R F}\right)_{\text {max }}$, (Iint RF ) avg - minimum, maximum, arithmetic mean values of indicators (Int RF ) among all types of commodity groups of high-tech products; $\sigma_{1}\left(\sigma_{2}\right)$ standard deviations in terms of indicators (Int $\mathrm{RF}$ ) among product groups for which the values of this indicator do not exceed (exceed) the average value (Iint RF ) avg •

Depending on the value of the integral indicator of competitiveness in the domestic market, products fall into one of four groups (Table 2), while the indicator of competitiveness of products in the domestic market is assigned a level (maximum, above average, below average, minimum) and a score in accordance with the gradations of the 10-point scale (Table 3).

Table 3. Scale of point assessment of the indicator values depending on the level of the integral indicator of competitiveness in the domestic market

\begin{tabular}{|l|c|}
\hline Indicator level & Score \\
\hline Maximum & 10.0 \\
\hline Above average & 7.5 \\
\hline Below average & 5.0 \\
\hline Minimum & 2.5 \\
\hline
\end{tabular}

The score assigned to the integral indicator of competitiveness determines the priority of high-tech products in the domestic market of Russia (Table 4).
Table 4. The level of priority of high-tech products in terms of competitiveness in the domestic market, depending on the assigned score

\begin{tabular}{|l|c|}
\hline Product Priority Level & Score indicator \\
\hline Highest priority & 10.0 \\
\hline Medium priority & 7.5 \\
\hline Lowest priority & 5.0 or 2.5 \\
\hline
\end{tabular}

By analogy with the above procedure, high-tech products are assessed for each component of the integral indicator of competitiveness in the domestic market: Int demand ; Int offer ; Int ${ }^{\mathrm{IZ}}$. The procedure for calculating indicators is shown in Table 5.

\subsection{Assessment of the Competitiveness of the Main Products of High-Tech Industries in the Region on the Global Commodity Markets}

The goal is to differentiate the region's high-tech products based on the potential of global supply and demand for three priorities (highest, middle, priority, lowest), each of which is assigned based on the calculation of the integral indicator of the potential to enter global commodity markets.

The calculation of the integral indicator of the world potential based on supply and demand (Int VN ) is carried out according to the formula $[8 ; 9]$ :

$$
\text { Int } \mathrm{VN}=\text { Int } \mathrm{VNdemand} * 0.5+\text { Int } \mathrm{VN} \text { offer } * 0.5
$$

where Int VNdemand is an integral indicator of the potential for entering the world commodity markets based on demand research; Int VNoffer is an integral indicator of potential entering global commodity markets based on supply research; 0.5 - weighting coefficients of the significance of indicators.

In relation to each obtained value of the integral indicator of the global potential of a commodity group on the basis of supply and demand (Int ${ }^{\mathrm{VN}}$ ), its place is determined among the values of indicators for all commodity groups with a distribution into four levels (maximum, above average, below average, minimum) and assigning an appropriate point estimates by analogy with the indicator Int ${ }^{R F}$.

Depending on the score assigned to the indicator for the corresponding product group, the priority of promoting such high-tech products in the global commodity markets is determined (Table 6). 
Table 5. Calculation of integral indicators of the competitiveness of high-tech products in the domestic market of the Russian Federation by consumer industries, competitors and the potential of import substitution.

\begin{tabular}{|c|c|c|c|}
\hline \multirow[t]{2}{*}{ Indicator } & \multicolumn{3}{|c|}{ Integral indicators of competitiveness } \\
\hline & by industry-consumer (Int demand $)$ & by competitors (Int ${ }^{\text {offer }}$ ) & $\begin{array}{c}\text { by import substitution potential (Int } \\
\text { IZ })\end{array}$ \\
\hline Target & $\begin{array}{l}\text { Assessment of the } \\
\text { competitiveness of the main } \\
\text { products of high-tech industries } \\
\text { in the region based on the study } \\
\text { of demand trends }\end{array}$ & $\begin{array}{l}\text { Assessment of the competitiveness of the } \\
\text { main products of high-tech industries in } \\
\text { the region based on the study of trends in } \\
\text { the offer of competitors }\end{array}$ & $\begin{array}{l}\text { Assessment of the competitiveness } \\
\text { of the main products of high-tech } \\
\text { industries in the region based on the } \\
\text { study of the potential of import } \\
\text { substitution }\end{array}$ \\
\hline $\begin{array}{l}\text { Calculation } \\
\text { formula }\end{array}$ & $\begin{array}{l}\text { Int demand }=\operatorname{Tr}^{\mathrm{B}} * 0.4+\mathrm{MS} * \\
0.4+\mathrm{KP} * 0.1+\mathrm{Tr}^{\mathrm{H}} * 0.1,(3) \\
\text { where: } \\
\text { - } \mathrm{Tr}^{\mathrm{B}} \text { is the rate of change in } \\
\text { the volume of demand for } \\
\text { high-tech products (the rate of } \\
\text { growth of gross revenue of } \\
\text { consumer industries over } 5 \\
\text { years); } \\
\text { - MS is the level of the scale of } \\
\text { demand for high-tech } \\
\text { products (the share of the } \\
\text { consumer industry in the GDP } \\
\text { of the Russian Federation); } \\
\text { - KP - the level of } \\
\text { concentration of consumers of } \\
\text { high-tech products; } \\
\text { - Tr }{ }^{\mathrm{H}} \text { is the rate of change in } \\
\text { the number of consumers of } \\
\text { high-tech products (the rate of } \\
\text { growth of gross revenue of } \\
\text { consumer industries over } 5 \\
\text { years); } \\
-0.4,0.4,0.1 \text { and } 0.1 \text { are the } \\
\text { weight coefficients of the } \\
\text { significance of the indicators. }\end{array}$ & $\begin{array}{l}\text { Int offer }=\operatorname{Tr} \mathrm{VK} * 0.4+\mathrm{MS}^{\mathrm{K}} * 0.4+\mathrm{KP} \\
\mathrm{K} * 0.1+\mathrm{Tr} \mathrm{ChK} * 0.1,(4) \\
\text { where: } \\
\text { - } \mathrm{Tr} \mathrm{VK} \text { - the rate of change in the } \\
\text { volume of supply of high-tech } \\
\text { products (the rate of growth of gross } \\
\text { revenue of competing industries over } \\
5 \text { years); } \\
\text { - MS }{ }^{\mathrm{K}} \text { - the level of the scale of supply } \\
\text { of high-tech products (the share of the } \\
\text { competing industry in the GDP of the } \\
\text { Russian Federation); } \\
\text { - KP } \mathrm{K} \text { - the level of concentration of } \\
\text { production in the industry; TrChK - } \\
\text { the rate of change in the number of } \\
\text { competitors of high-tech products (the } \\
\text { rate of growth of gross revenue of } \\
\text { competing industries over } 5 \text { years); } \\
\text { - } 0.4,0.4,0.1 \text { and } 0.1 \text { are the weight } \\
\text { coefficients of the significance of the } \\
\text { indicators. }\end{array}$ & $\begin{array}{l}\text { Int }{ }^{\mathrm{IZ}}=\mathrm{I}^{\mathrm{D}} * 0.7+\operatorname{Tr}^{\mathrm{I}} * 0.3(5) \\
\text { where: } \\
\text { - I }{ }^{\mathrm{D}} \text { - the share of imports of high- } \\
\text { tech products (the share in the } \\
\text { difference between the volume } \\
\text { of domestic production and the } \\
\text { volume of Russian exports of } \\
\text { these products); } \\
\text { - Tr }{ }^{\mathrm{I}} \text { is the rate of change in the } \\
\text { volume of imports of high-tech } \\
\text { products to Russia (the rate of } \\
\text { increase in gross imports over } 5 \\
\text { years); } \\
\text { - } 0.7 \text { and } 0.3 \text { are the weighting } \\
\text { coefficients of the significance } \\
\text { of the indicators. }\end{array}$ \\
\hline Initial data & $\begin{array}{l}\text { Rosstat database, IS SPARK } \\
\text { Interfax, websites of enterprises } \\
\text { of industries consuming high- } \\
\text { tech products }\end{array}$ & $\begin{array}{l}\text { Rosstat database, IS SPARK Interfax, } \\
\text { sites of competitors' enterprises for the } \\
\text { production of high-tech products }\end{array}$ & $\begin{array}{l}\text { Rosstat DB, IS SPARK Interfax, } \\
\text { results of a survey of business } \\
\text { representatives }\end{array}$ \\
\hline
\end{tabular}

Table 6. The level of priority of high-tech products according to the indicator of global potential, depending on the assigned score

\begin{tabular}{|l|c|}
\hline Product Priority Level & Score indicator \\
\hline Highest priority & 10.0 \\
\hline Medium priority & 7.5 \\
\hline Lowest priority & 5.0 or 2.5 \\
\hline
\end{tabular}

Initial data for calculating the integral indicator and its components - DB FSGS, IS SPARK Interfax, Federal Customs Service of the Russian Federation, International Database of Foreign Trade.

By analogy with the above procedure, high-tech products are assessed for each individual indicator, which is a component of the calculation of the integral indicator of world potential: Int VN demand ; Int VNoffer The procedure for calculating each such indicator is shown in Table 7.

\subsection{Building a Positioning Matrix for High- Tech Products in the Region}

The goal of the stage is to form portfolios of hightech products for promotion on the national and global commodity markets.

At this stage, a consolidated matrix for positioning high-tech products of the region is being built for the development of national and global commodity markets according to the priority of their promotion (table 8) 
Table 7. Calculation of integral indicators of the competitiveness of high-tech products in world markets based on research on demand and offer

\begin{tabular}{|c|c|c|}
\hline Indicator & $\begin{array}{c}\text { Integral indicator of the potential for entering the } \\
\text { world commodity markets based on demand } \\
\text { research (Int VNdemand })\end{array}$ & \begin{tabular}{|c|}
$\begin{array}{c}\text { Integral indicator of the potential for entering the } \\
\text { world commodity markets based on supply research } \\
\text { (Int VNoffer })\end{array}$ \\
\end{tabular} \\
\hline Target & $\begin{array}{l}\text { Assessment of world commodity markets for high- } \\
\text { tech products based on research on demand trends }\end{array}$ & $\begin{array}{l}\text { Assessment of world high-tech product markets } \\
\text { based on offer research }\end{array}$ \\
\hline $\begin{array}{l}\text { Calculation } \\
\text { formula }\end{array}$ & $\begin{array}{l}\text { Int } \mathrm{VN} \text { demand }=\mathrm{D} \operatorname{Im} * 0.5+\mathrm{Tr} \operatorname{Im} * 0.5(7) \\
\text { where: } \\
\text { - } \mathrm{D}^{\mathrm{Im}} \text { - the scale of demand for a certain type of } \\
\text { high-tech products in the world (the share of } \\
\text { imports of a certain type of high-tech products } \\
\text { in the total volume of imports of high-tech } \\
\text { products); } \\
\text { - Tr }{ }^{\mathrm{Im}} \text { - the rate of change in the volume of world } \\
\text { imports of a certain type of high-tech products } \\
\text { (the rate of increase in the volume of imports } \\
\text { over } 5 \text { years); } \\
\text { - } 0.5 \text { and } 0.5 \text { are the weighting coefficients of the } \\
\text { significance of the indicators. }\end{array}$ & $\begin{array}{l}\text { Int }{ }^{\mathrm{VNoffer}}=\mathrm{D}^{\mathrm{E} * 0.5+\mathrm{Tr}} \mathrm{E} * 0.5(8) \\
\text { where: } \\
-\mathrm{D}^{\mathrm{E}} \text { - the scale of supply of a certain type of high- } \\
\text { tech products in the world (the share of exports } \\
\text { of a certain type of high-tech products in the } \\
\text { total export of high-tech products); } \\
-\mathrm{Tr}^{\mathrm{E}} \text { - the rate of change in the volume of exports } \\
\text { of a certain type of high-tech products (the rate } \\
\text { of increase in the volume of exports over } 5 \\
\text { years); } \\
-0.5 \text { and } 0.5 \text { are the weighting coefficients of the } \\
\text { significance of the indicators. }\end{array}$ \\
\hline Initial data & $\begin{array}{l}\text { DB FSGS, IS SPARK Interfax, Federal Customs } \\
\text { Database of Foreign Trade }\end{array}$ & $\operatorname{ian} \mathrm{F}$ \\
\hline
\end{tabular}

Table 8. Matrix of positioning high-tech products of the region.

\begin{tabular}{|c|c|c|c|c|}
\cline { 3 - 5 } \multicolumn{2}{c|}{} & \multicolumn{3}{c|}{ Priority of promotion on global commodity } \\
markets
\end{tabular}

Based on the results of the grouping of high-tech products, two portfolios are formed:

- products with the highest and medium priority levels for promotion in the domestic market of Russia;

- products with the highest and medium priority levels for promotion on global commodity markets.

In the case of simultaneous priority of products for the domestic and foreign markets, the products fall into both product portfolios.

Initial data - the results of calculating the indicators of the 2 nd and 3 rd stages.
Thus, a system of step-by-step assessment and achievement of the set goals has been built.

\section{RESULTS AND DISCUSSION}

As an approbation of this approach, the results of the selection of high-tech industries in the economy of the Krasnoyarsk Territory and an assessment of the competitiveness of high-tech products in the national market are presented. At the same time, the potential of domestic demand for high-tech products was assessed by consumer industries, the potential of product supply by competitors, the potential of import substitution - by the rate of change in the volume of imports of high-tech products to Russia.

The calculation of the final integral indicator of competitiveness in the domestic market was carried out on the basis of formula (2), the results are presented in table 9. By analogy, the assessment of the competitiveness of high-tech industries in the region in the world commodity markets was carried out on the basis of a study of demand (Int VNdemand) and offer (Int vNoffer $)$. The results are shown in Table 10.

Positioning of high-tech products for selected hightech enterprises in the region in the matrix "priority of promotion in the global commodity markets - priority of promotion in the domestic market of the Russian Federation" allowed the formation of portfolios of hightech businesses. 
Table 9. Assessment of the competitiveness of the main products of high-tech industries in the region in the domestic market of the Russian Federation (Int ${ }^{\mathrm{RF}}$ ) - fragment.

\begin{tabular}{|c|c|c|c|c|c|c|c|c|}
\hline \multirow[b]{2}{*}{ Industry (OKVED) } & \multirow[b]{2}{*}{$\begin{array}{l}\text { Sub-industry } \\
\text { (OKVED) }\end{array}$} & \multirow[b]{2}{*}{ Products } & \multicolumn{6}{|c|}{ Integral indicator of competitiveness (Int ${ }^{\mathrm{RF}}$ ) } \\
\hline & & & $\begin{array}{c}\text { Int } \\
\text { demand }\end{array}$ & $\begin{array}{l}\text { Int } \\
\text { offer }\end{array}$ & $\begin{array}{l}\text { Int } \\
\text { IZ }\end{array}$ & Value & Points & $\begin{array}{c}\text { Priority } \\
\text { level }\end{array}$ \\
\hline \multirow[t]{2}{*}{$\begin{array}{l}26 \text { Manufacture of } \\
\text { computers, electronic } \\
\text { and optical products }\end{array}$} & $\begin{array}{l}26.30 .17 \text { Manufacture } \\
\text { of radio and television } \\
\text { transmitting } \\
\text { equipment }\end{array}$ & $\begin{array}{l}\text { Wireless } \\
\text { underground alarm } \\
\text { system, "Radius" } \\
\text { system }\end{array}$ & 7.5 & 7.5 & 5 & 6.5 & 7.5 & average \\
\hline & $\begin{array}{l}\text { 26.30.4 Production of } \\
\text { antennas, antenna } \\
\text { reflectors of all types } \\
\text { and their parts }\end{array}$ & $\begin{array}{l}\text { Line of homing } \\
\text { satellite antennas } \\
\text { SAS, satellite modem }\end{array}$ & 7.5 & 7.5 & 7.5 & 7.5 & 7.5 & higher \\
\hline \multirow{3}{*}{$\begin{array}{l}26.51 \text { Manufacture of } \\
\text { instruments and } \\
\text { appliances for } \\
\text { measuring, testing and } \\
\text { navigation }\end{array}$} & $\begin{array}{l}\text { 26.51 Manufacture of } \\
\text { tools and devices... }\end{array}$ & $\begin{array}{l}\text { Portable luminometer } \\
\text { "LumiShot+", } \\
\text { Reagent } \\
\text { "Enzymolum" }\end{array}$ & 5 & 10 & 0.0 & 4 & 5 & lower \\
\hline & $\begin{array}{l}\text { 26.51.5 Manufacture } \\
\text { of instruments for the } \\
\text { control of other } \\
\text { physical quantities }\end{array}$ & $\begin{array}{l}\text { Conveyor protective } \\
\text { complex (KKZ-1M), } \\
\text { Ore Control Station } \\
(\mathrm{RKS}-\mathrm{KM})\end{array}$ & 7.5 & 7.5 & 7.5 & 7.5 & 7.5 & average \\
\hline & $\begin{array}{l}\text { 26.20 Manufacture of } \\
\text { computers and } \\
\text { peripheral equipment; }\end{array}$ & $\begin{array}{l}\text { Indigo 3D Alpha 3D } \\
\text { Printer, Remote } \\
\text { Control Universal } \\
\text { Controller }\end{array}$ & 7.5 & 7.5 & 5 & 6.5 & 7.5 & average \\
\hline \multirow[t]{2}{*}{$\begin{array}{l}27 \text { Manufacture of } \\
\text { electrical equipment }\end{array}$} & $\begin{array}{l}\text { 27.40 Manufacture of } \\
\text { electric lamps and } \\
\text { lighting equipment }\end{array}$ & $\begin{array}{l}\text { LED luminaires for } \\
\text { industrial, street, } \\
\text { office. }\end{array}$ & 7.5 & 7.5 & 5 & 6.5 & 7.5 & average \\
\hline & $\begin{array}{l}\text { 27.11 Manufacture of } \\
\text { electric motors, } \\
\text { generators and } \\
\text { transformers }\end{array}$ & $\begin{array}{l}\text { Diesel generator sets, } \\
\text { block containers, } \\
\text { diesel power plants }\end{array}$ & 7.5 & 7.5 & 5 & 6.5 & 7.5 & average \\
\hline \multirow[t]{2}{*}{$\begin{array}{l}28 \text { Production of } \\
\text { machinery and } \\
\text { equipment not included } \\
\text { in other groups }\end{array}$} & $\begin{array}{l}28.30 .3 \text { Manufacture } \\
\text { of machinery and } \\
\text { agricultural } \\
\text { equipment }\end{array}$ & $\begin{array}{l}\text { Rotary subsoiler, } \\
\text { Protective conveyor } \\
\text { complex (KKZ-1MP) }\end{array}$ & 7.5 & 7.5 & 7.5 & 7.5 & 7.5 & average \\
\hline & $\begin{array}{l}\text { 28.92 Manufacture of } \\
\text { machinery and } \\
\text { equipment for mining }\end{array}$ & $\begin{array}{l}\text { Side blades for light } \\
\text { and heavy graders. } \\
\text { Forklifts. Front } \\
\text { loaders }\end{array}$ & 10 & 7.5 & 10 & 9.5 & 10 & higher \\
\hline
\end{tabular}

The main criterion for the formation of portfolios of high-tech businesses in the Krasnoyarsk Territory is the inclusion of products in the groups of higher and medium priorities in the corresponding dimensions.

Based on the assessment of the competitiveness of the products of high-tech industries in the region in the domestic market of the Russian Federation and world markets, based on the trends existing in them, three portfolios of competitive high-tech businesses of the Krasnoyarsk Territory were formed (Table 10):

- a portfolio of competitive high-tech businesses for the national market (including taking into account the potential of import substitution);

- a portfolio of competitive import-substituting hightech products for the national market;

- a portfolio of competitive high-tech businesses for the global market.
The results of a survey of high-tech industries made it possible to compile a list of the nomenclature of products and new products planned for release. The main share (94\%) was made up of existing products: the production of computers, electronic and optical products $-36 \%$, the production of machinery and equipment $30 \%$, the production of electrical equipment and other vehicles and equipment - $14 \%$ each. The supply of products to the Russian market amounted to $64 \%$, simultaneously to the domestic and foreign markets $36 \%$. Current export countries are China, Great Britain, Slovakia, Estonia, Ukraine, Kazakhstan, Belarus, Armenia, Angola. An information and analytical system for assessing the commodity markets of high-tech products has been formed, focused not only on the national scale of consumption, including taking into account import substitution, but also global country and industry trends in their development. 
Table 10. The overall portfolio of competitive high-tech products of the Krasnoyarsk Territory according to the priority of promotion in the national and world markets (fragment).

\begin{tabular}{|c|c|c|c|c|c|c|c|c|c|c|c|c|}
\hline \multirow{3}{*}{\multicolumn{2}{|c|}{$\begin{array}{l}\text { Industry / sub- } \\
\text { industry } \\
\text { (OKVED) }\end{array}$}} & \multirow{3}{*}{ Enterprises } & \multirow{3}{*}{ Products } & \multicolumn{9}{|c|}{ Promotion priority } \\
\hline & & & & \multicolumn{3}{|c|}{ Domestic market } & \multicolumn{3}{|c|}{ Import substitution } & \multicolumn{3}{|c|}{$\begin{array}{c}\text { Foreign } \\
\text { market }\end{array}$} \\
\hline & & & & B & C & $\mathrm{H}$ & B & $\mathrm{C}$ & $\mathrm{H}$ & $\mathrm{B}$ & $\mathrm{C}$ & $\mathrm{H}$ \\
\hline \multirow[t]{2}{*}{26} & 26.30 .17 & $\begin{array}{l}\text { JSC Scientific } \\
\text { Research Center } \\
\text { "Radius" }\end{array}$ & $\begin{array}{l}\text { Wireless underground } \\
\text { alarm system, "Radius" } \\
\text { system }\end{array}$ & & & & & & & & & \\
\hline & 26.30 .4 & $\begin{array}{l}\text { LLC "Engineering- } \\
\text { ring bureau } \\
\text { "Phoenix" }\end{array}$ & $\begin{array}{l}\text { Line of homing satellite } \\
\text { antennas SAS, satellite } \\
\text { modem }\end{array}$ & & & & & & & & & \\
\hline \multirow[t]{3}{*}{26.51} & 26.51 & $\begin{array}{l}\text { LLC NPP Applied } \\
\text { Biosystems }\end{array}$ & $\begin{array}{l}\text { Portable luminometer } \\
\text { "LumiShot+", } \\
\text { Reagent "Enzymolum" }\end{array}$ & & & & $\mathrm{n} / \mathrm{a}$ & $\mathrm{n} / \mathrm{a}$ & $\mathrm{n} / \mathrm{a}$ & & & \\
\hline & 26.51 .5 & LLC "Technoros" & $\begin{array}{l}\text { Conveyor protective } \\
\text { complex (KKZ-1M), Ore } \\
\text { Control Station (RKS- } \\
\text { KM) }\end{array}$ & & & & & & & & & \\
\hline & 26.20 & Kisan LLC & $\begin{array}{l}\text { Indigo 3D Alpha 3D } \\
\text { Printer, Remote Control } \\
\text { Universal Controller }\end{array}$ & & & & & & & & & \\
\hline \multirow[t]{2}{*}{27} & 27.40 & Kisan LLC & $\begin{array}{l}\text { LED luminaires for } \\
\text { industrial, street, office. }\end{array}$ & & & & & & & & & \\
\hline & 27.11 & LLC "MegaWatt" & $\begin{array}{l}\text { Diesel generator sets, } \\
\text { block containers, diesel } \\
\text { power plants }\end{array}$ & & & & & & & & & \\
\hline \multirow[t]{2}{*}{28} & 28.30 .3 & LLC "Technoros" & $\begin{array}{l}\text { Rotary subsoiler, } \\
\text { Protective conveyor } \\
\text { complex (KKZ-1MP) }\end{array}$ & & & & & & & & & \\
\hline & 28.92 & LLC "BORUS" & $\begin{array}{l}\text { Side blades for light and } \\
\text { heavy graders. Forklifts. } \\
\text { Front loaders }\end{array}$ & & & & & & & & & \\
\hline
\end{tabular}

Accepted designations: $\mathrm{n} / \mathrm{a}$ - no data.

\section{CONCLUSIONS}

The methodology presented in the article for selecting promising commodity markets for high-tech products in the region, based on multi-criteria assessments of market positioning parameters, allows us to build a process of managing structural changes in the economic system of the region with the support of appropriate business incentive mechanisms.

The proposed methodological approach to the formation of a portfolio of high-tech businesses in the economic system of the region makes it possible to come up with various options for its use to ensure sustainable economic development of the region.

The practical significance of the research results for business lies in the possibility of assessing the prospects for entering national and global commodity markets, for the region and the supervising ministries - in identifying commodity markets in order to determine the possibilities of optimizing the structural elements of the economic system of the region and improving their support mechanisms;

building the process of selecting promising markets for the region's raw materials, followed by reaching strategic priorities for increasing the science-intensive and technological effectiveness of the region's economic system;

organization of monitoring of promising commodity markets for high-tech products to develop recommendations to improve their competitiveness;

making adjustments to the existing regional mechanisms to support the development and promotion of high-tech businesses in the region to the world commodity markets, forming roadmaps in accordance with the identified priorities, strategies and scenarios of structural changes.

The research was carried out within the framework of the project "Research of the potential of new materials technologies, technologies for the production of new types of high-tech products and mechanisms of cooperation of regional producers for the implementation of priority investment projects and strategic repositioning in the world commodity markets" (application code No. 2021020107139) with the support of the Krasnoyarsk Regional Science Foundation. 


\section{REFERENCES}

[1] V. D. Markova, S. A. Kuznetsova, Features of the development of high-tech business, Economics. Profession. Business, S1 (2016) pp. 7-11.

[2] A. N. Spartak, A. E. Likhachev, Export potential of Russia in innovative segments of the world market, Russian Foreign Economic Bulletin, 10 (2017) pp. 3-22.

[3] O. Yu. Ermolovskaya, A. P. Milovanov, High-tech export within the framework of the priorities of socio-economic development of Russia, Economics and Management: Problems of Solution, 2(3) (2019) pp. 13-20.

[4] G. L. Azoev, Marketing: mastering the profession, St. Petersburg, 2018, pp. 62.

[5] A. N. Rusina, O. V. Karpycheva, I. V. Filimonenko, Identifying professions in demand and areas of training in the regional labor market, Creative Economy, 11(11) (2017) pp. 1145-1156. DOI: https://doi.org/10.18334 / ce.11.11.38565.

[6] Order of the Federal State Statistics Service of December 15, 2017 No. 832 "On approval of the Methodology for calculating the indicators "The share of products of high-tech and knowledgeintensive industries in the gross domestic product" and "The share of products of high-tech and knowledge-intensive industries in the gross regional product of the subject of the Russian Federation".

[7] O. V. Ryzhkova, A. V. Latynina, M. A. Likhachev, Methodology for assessing the potential for the formation of high-tech industries for structural changes in the economic system of a raw material region, Economics, Entrepreneurship and Law, 10(9) (2020) pp. 2339-2354. DOI: https://doi.org/10.18334/epp.10.9.110820.

[8] A. S. Bondareva, The global market of high-tech products as a factor in increasing the competitiveness of the Russian economy in the context of globalization, Symbol of Science, 8 (2018) pp. 23-26. https://elibrary.ru/item.asp?id=35512596.

[9] I. O. Mylykhina, Stimulation of high-tech industries as an imperative of technological development of the domestic economy, Issues of innovative economics, 9(4) (2019) pp. 1469-1478. DOI: https://doi.org/10.18334/vinec.9.4.41251.

[10] A. N. Spartak, A. Yu. Knobel, T. A. Flegontova, Prospects for increasing Russian non-resource exports, Russian export center. M.: TsSR Economic Development, 2018, pp. 132.
[11] I. N. Trefilova, E. V. Kassyura, Assessment of the role of marketing in the formation of the innovative potential of high-tech companies in the value chain, Bulletin of SUSU. Ser. Economics and Management, 11 (1) (2017) pp. 149-159.

[12] E. I. Safarova, I. V. Khalitov, V. S. Ismagilov, Experience of foreign countries in the field of state support and export promotion, Bulletin of the Bashkir University, 22(2) (2017) pp. 568-572. 